\title{
Effects of seasonal hypoxia on macrobenthic production and function in the Rappahannock River, Virginia, USA
}

\author{
S. Kersey Sturdivant ${ }^{1, *}$, Rochelle D. Seitz $^{2}$, Robert J. Diaz ${ }^{2}$ \\ ${ }^{1}$ Division of Marine Science and Conservation, Nicholas School of the Environment, Duke University, \\ 135 Duke Marine Lab Rd., Beaufort, North Carolina 28516, USA \\ ${ }^{2}$ Virginia Institute of Marine Science, College of William \& Mary, PO Box 1346, Gloucester Pt., Virginia 23062, USA
}

\begin{abstract}
Since colonial times, anthropogenic effects have eroded Chesapeake Bay's health, resulting in an increase in the extent and severity of hypoxia $\left(\leq 2 \mathrm{mg} \mathrm{O}_{2} \mathrm{l}^{-1}\right)$, adversely affecting community structure and secondary production of macrobenthos in the Bay and its tributaries. The influence of hypoxia on macrobenthic communities is well documented, but less well known is the regulatory effect of hypoxia on macrobenthic production. Changes in macrobenthic production were assessed in the lower Rappahannock River, a sub-estuary of Chesapeake Bay, in an area known to experience seasonal hypoxia. During the spring, summer, fall, and following spring of 2007 and 2008, 10 samples were collected each season for a total of 80 samples, and macrobenthic production was estimated using Edgar's allometric equation. Additionally, from early spring to late fall, dissolved oxygen concentrations were measured continuously at 2 of the 10 sites in 2007, and 2 of the 10 sites in 2008; in conjunction, the macrobenthic community was assessed through bi-weekly grab samples at these sites. Hypoxic sites had as much as $85 \%$ lower macrobenthic production compared to normoxic sites, and macrobenthic production at hypoxic sites was associated with primarily smaller, disturbance-related annelids. Macrobenthic production differed across seasons, and estimated sediment reworking rates were significantly higher during normoxia, indicating that the functional role of the macrobenthic community changed during hypoxia.
\end{abstract}

KEY WORDS: Oxygen depletion - Secondary production - Chesapeake Bay · Macrobenthos · Energy flow Resale or republication not permitted without written consent of the publisher

\section{INTRODUCTION}

Oxygen, a key element in the metabolic processes of most metazoan organisms, is found in a dissolved form in aquatic environments as a result of primary production and atmospheric diffusion (Breitburg et al. 2003). In estuaries, once dissolved into surface waters, dissolved oxygen (DO) is normally mixed down into bottom waters by turbulence or gravitational circulation (Kuo \& Neilson 1987, Burchard \& Schuttelaars 2012). During the spring and summer months, a pycnocline develops as a result of the spring freshet and warmer surface waters (Taft et al. 1980). This stratification hampers the supply of DO to bottom waters, and as the consumption rate exceeds resupply, DO concentrations decline, and the system can experience hypoxia (Kemp et al. 2005). We define hypoxia as DO concentrations of $\leq 2 \mathrm{mg} \mathrm{O}_{2} \mathrm{l}^{-1}$, mild hypoxia as 2.1 to $2.8 \mathrm{mg} \mathrm{O}_{2} \mathrm{l}^{-1}$, normoxia as $>2.8 \mathrm{mg} \mathrm{O}_{2} \mathrm{l}^{-1}$, and anoxia as the complete absence of oxygen (Tyson \& Pearson 1991).

Hypoxia is closely associated with eutrophication arising from altered coastal nutrient budgets that can be linked to increased human population, whether through urbanization in coastal river drainages or through expanded agricultural activities (Diaz 2001). Though intermittent hypoxia in the Bay may have been a natural phenomenon, sediment cores indicate 
that the frequency and extent of hypoxia increased with colonization and subsequent land cover changes (Cooper \& Brush 1991, Cooper 1995, Hagy et al. 2004). Anthropogenic disturbance has resulted from activities that mobilize nitrogen and phosphorous compounds through land clearing, application of fertilizer, discharge of human waste, animal production, and combustion of fossil fuels (Cloern 2001). In Chesapeake Bay, runoff from agricultural practices is the main source of nutrient loading (Magnien et al. 1995).

Seasonal hypoxia occurs throughout Chesapeake Bay and some of its tributaries during the summer months, and was first detected in DO measurements in the Potomac (a tributary) in the 1910s (Sale \& Skinner 1917), and in the main stem Chesapeake Bay in the early 1930s (Newcombe et al. 1939, Zimmerman \& Canuel 2000). The most severe low-oxygen events, in terms of duration and DO concentration, occur in the main stem (Officer et al. 1984, Stow \& Scavia 2009), and hypoxic conditions in the Bay last approximately 120 d (May to September; Murphy et al. 2011). From the 1950s through the 1990s, there has been a substantial increase in hypoxic/anoxic water in Chesapeake Bay, from $\sim 3 \mathrm{~km}^{3}$ in the $1950 \mathrm{~s}$, to $\sim 10 \mathrm{~km}^{3}$ in the 1990s (Hagy et al. 2004), with no decline in the 21st century (Murphy et al. 2011). The increase in the spatial extent of Chesapeake Bay hypoxia has consequences for the benthos (Riedel et al. 2008, Vaquer-Sunyer \& Duarte 2008, Van Colen et al. 2010). While gravitational circulation drives hypoxia development in the Bay (Kuo \& Neilson 1987), the outer edge of Chesapeake Bay's main stem hypoxic water may be advected into shallow areas, such as the Bay's tributaries, through horizontal transport (Breitburg 1990). In the Rappahannock River, our area of interest, a combination of tidal mixing and proximity to main-stem hypoxic waters controls the seasonal hypoxia, which lasts throughout most of the summer (Kuo \& Neilson 1987, Kuo et al. 1991, Park et al. 1996).

The effects of hypoxia on benthic community structure are generally understood to include a series of predictable and graded responses (Rabalais et al. 2001). At the initial onset of hypoxia, organisms increase respiration (Wannamaker \& Rice 2000), and mobile fauna migrate from the area (Ludsin et al. 2009, Seitz et al. 2009). As DO further declines, sessile fauna cease feeding and decrease activities not related to respiration (Diaz \& Rosenberg 1995). Infauna migrate closer to the sediment surface as reduced compounds (e.g. $\mathrm{H}_{2} \mathrm{~S}$ ) accumulate, and have been observed on or extending above the sediment surface in a moribund condition (Tyson \& Pearson 1991, Long et al. 2008, Sturdivant et al. 2012). Finally, if the duration of hypoxia is sustained, mass mortality occurs in all but the most tolerant species (Llansó 1992, Diaz \& Rosenberg 1995, Levin et al. 2009). At the functional level, there is less understanding of how hypoxia interacts with macrobenthic production and the subsequent trophic transfer of energy (Baird et al. 2004, Long \& Seitz 2008).

Productivity is an intriguing component of the energy budget in marine benthic habitats, as it provides an index of community processes proportional to total community respiration and consumption, and it integrates the influence of numerous biotic and environmental variables affecting individual growth and population mortality (Edgar \& Barrett 2002, Cusson \& Bourget 2005). Production can be defined as the quantity of matter or energy that is available for the next higher trophic level, and an estimate of productivity can be obtained by relating the calculated production to the biomass present (Dolbeth et al. 2012). Secondary production, or the heterotrophic production of organic matter, is viewed as an estimate of estuarine health (Diaz \& Schaffner 1990, Dolbeth et al. 2005). The production of macrobenthos is important, as these fauna serve as a link in the energy transfer from primary consumers to higher trophic levels (Nilsen et al. 2006), and is a pathway by which organic carbon is recycled out of the sediment and eventually out of Chesapeake Bay system (Diaz \& Schaffner 1990). Community production is rarely measured directly, due to methodological difficulties (Edgar 1990). While direct calculations of macrobenthic production are costly and time-consuming (Wilber \& Clarke 1998), methods have been proposed for the indirect calculation of macrobenthic production based on biotic and abiotic variables (e.g. Robertson 1979, Banse \& Mosher 1980, Schwinghamer et al. 1986, Plante \& Downing 1989, Brey 1990, 2001, Edgar 1990, Morin \& Bourassa 1992, Sprung 1993, Tumbiolo \& Downing 1994); recent reviews by Cusson \& Bourget (2005) and Dolbeth et al. (2005) evaluated a number of these models and concluded that they reliably estimate secondary production. Measuring or estimating production is useful as it express all the components of an ecosystem in common units, allowing the function of the system to be better understood (Lindeman 1942). With production, thermodynamics acts as the common denominator defining the manner of energy transformation and ecological usefulness of varying energy forms (Benke et al. 1988, Wiegert 1988). The error associated with these broad habitat predictions is large, but the value 
in the prediction is the ability to provide a relative starting point for assessing the magnitude of energy flow through the macrobenthos (Diaz \& Schaffner 1990).

Using production theory and empirical models developed to quantify macrobenthic production without the requirement of intense sampling, we aimed to relate patterns of macrobenthic production in the Rappahannock River estuary to DO concentrations. Specific objectives of our study were to (1) assess the relationship between macrobenthic production and the physical factors of DO concentration, salinity, and \% silt and clay; (2) describe patterns of macrobenthic production temporally (across weeks and seasons); and (3) determine taxonomic associations between macrobenthic production and DO concentration.

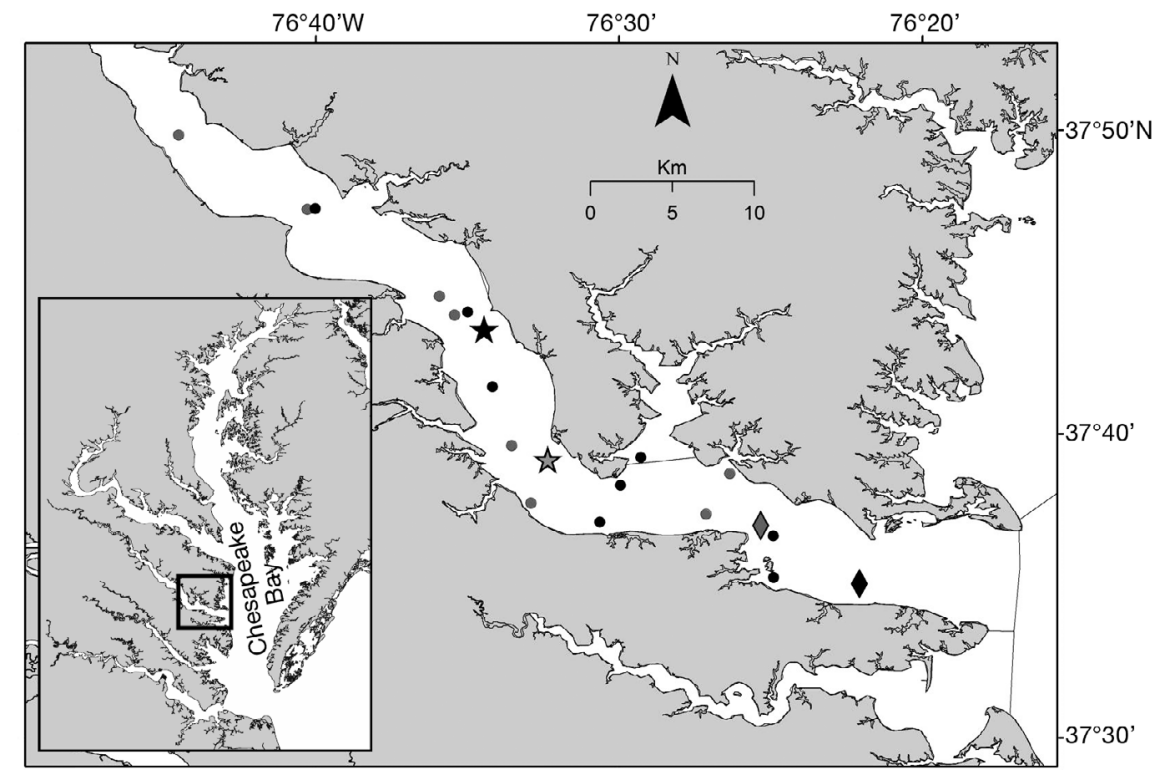

Fig. 1. Lower Rappahannock River depicting the spatial distribution of the 10 sites sampled in 2007 (gray symbols) and 2008 (black symbols), including special designation of the normoxic (diamond symbols) and hypoxic (star symbols) continuously monitored sites

\section{MATERIALS AND METHODS}

\section{Study area}

Of the 3 major tributaries of the lower Chesapeake Bay, the Rappahannock River is the only sub-estuary with the physical dynamics to allow sustained seasonal hypoxia (Kuo \& Neilson 1987). In the lower Rappahannock, a combination of tidal mixing and to a lesser extent, proximity to main stem hypoxic waters, controls its seasonal hypoxia, which develops in late May and abates in early September (Kuo et al. 1991, Park et al. 1996).

\section{Sampling design}

The Chesapeake Bay Long-Term Benthic Monitoring Program (LTBMP) started annual random sampling of Chesapeake Bay and its tributaries in both Maryland and Virginia in 1996. The LTBMP divided the Bay into 10 sampling strata, with each having 25 random sampling sites per year; the Rappahannock River is one stratum within the LTBMP design. Sites were sampled by the LTBMP from late July to early September, with a new set of random sites selected each year (Dauer \& Llansó 2003). Within the monitoring framework, we included 10 of the 25 randomly selected sites within the meso- and polyhaline portions of the Rappahannock River estuary (Fig. 1). The meso- and polyhaline regions of the Rappahannock River were selected due to a history of sustained seasonal hypoxia during the summer months (Kuo \& Neilson 1987, Park et al. 1996). In conjunction with the LTBMP summer sampling, all 10 sites were also sampled during the spring, and fall of 2007, and again in the spring of the following year (2008). This process was repeated with a new set of randomly selected sites in 2008, i.e. 10 sites sampled during the spring, summer, and fall of 2008 , and they were sampled again in the spring of the following year (2009). Thus, our sample period covered the spring of 2007 through the spring of 2009. By randomly selecting sites during consecutive years, our results represent an unbiased spatial assessment of the meso- and polyhaline Rappahannock River, as opposed to looking at fixed sites that would be representative of only those specific locations. In this manuscript when discussing the seasonal sampling and results, '1st spring' will refer to the first time that samples were collected in the spring of the stated sampling year, and '2nd spring' will refer to samples collected in the spring of the following year to assess recovery (i.e. 2nd spring 2007 refers to samples collected in the spring of 2008 at the 2007 random sites, 2nd spring 2008 refers to samples collected in the spring of 2009 at the 2008 random sites). 


\section{Field methods}

At each site, basic water quality parameters of DO concentration, salinity, and temperature were measured at the surface of the water column and approximately $0.5 \mathrm{~m}$ from the bottom using a YSI model 6600 datasonde. The mean depth of our seasonal sites in 2007 and 2008 was $6.4(\mathrm{SD}=3.2)$ and $6.3(\mathrm{SD}=3.4) \mathrm{m}$, respectively. Sediment grabs were collected for benthic community analysis using a Young grab $\left(440 \mathrm{~cm}^{2}\right.$ to a depth of $10 \mathrm{~cm}$ ). Samples were sieved in situ through a $0.5 \mathrm{~mm}$ screen using an elutriation process. Organisms and detritus retained on the screen were transferred into labeled jars and preserved in a 10\% formaldehyde solution. They were later stained with Rose Bengal, a vital stain that aids in separating organisms from sediments and detritus. Two surfacesediment sub-samples of approximately $120 \mathrm{ml}$ each were collected for grain-size analysis from an additional grab sample at each site.

Each year, 2 of the 10 sites were selected for continuous DO monitoring: in 2007, Sites 18 and 25, and in 2008, Sites 11 and 12. Site selection was based on DO concentration, with one site having a history of normoxia (Sites 25 and 12) and the other, hypoxia (Sites 18 and 11). Different sampling sites were selected each year, instead of a longer study of 2 sites, to ensure observed trends between sites were not anomalous, and due to the nominally normoxic site in 2007 experiencing hypoxia. Aside from DO and depth, the 2 sites chosen each year had similar physical parameters. At each location, a single tripod was deployed with a Hach DS500X water quality datasonde, positioned approximately $0.5 \mathrm{~m}$ above the sediment surface. DO concentration, salinity, and temperature measurements were recorded at $20 \mathrm{~min}$ increments for a $2 \mathrm{wk}$ period. Every $2 \mathrm{wk}$, datasondes were collected for maintenance and data retrieval, and new datasondes were deployed. Occasionally the datasondes malfunctioned and did not record data; these are represented by gaps in the continuous

Table 1 . Equations relating daily macrobenthic production $P$ $\left(\mu \mathrm{g} \mathrm{C} \mathrm{d}^{-1}\right)$ to faunal ash-free dry-weight $B(\mu \mathrm{g})$ and water temperature $T\left({ }^{\circ} \mathrm{C}\right)$ for different animal groups, where $\mathrm{p}=x \times B^{y} \times T^{z}$. Data derived from Edgar (1990)

\begin{tabular}{|lclcc|}
\hline & $x$ & $y$ & $z$ & Eq. \\
\hline General & 0.0049 & 0.8 & 0.89 & 1 \\
Polychaeta & 0.0035 & 0.79 & 1.05 & 5 \\
Crustacea & 0.0013 & 0.81 & 1.32 & 6 \\
Mollusca & 0.0066 & 0.87 & 0.46 & 7 \\
\hline
\end{tabular}

DO data, and are discussed further in the 'Results' section. Additional grab samples were collected at each site with a Young grab during the bi-weekly datasonde swap, and water quality control measurements were collected approximately $0.5 \mathrm{~m}$ from the bottom using a YSI model 6600 datasonde. The grab methodology described previously was implemented in the bi-weekly sampling.

\section{Laboratory methods}

All macrobenthic samples were processed to identify and enumerate each species present and to measure species-specific ash-free dry-weight (AFDW) biomass. Organisms were sorted from detritus under dissecting microscopes, identified to the lowest possible taxonomic unit, and counted. AFDW biomass was measured for each species by drying organisms to a constant weight at $60^{\circ} \mathrm{C}$ and ashing in a muffle furnace at $500^{\circ} \mathrm{C}$ for $4 \mathrm{~h}$. Sediment samples were wet-sieved for \% silt and clay content (Folk 1973).

\section{Macrobenthic production}

Edgar (1990) developed a general allometric equation $\left(\mathrm{p}=0.0049 \times B^{0.80} T^{0.89}\right)$ from a meta-analysis of production estimates for benthic macrofaunal populations that relates daily macrobenthic production $\left(P_{;}\right.$ $\mu \mathrm{g} \mathrm{C} \mathrm{d}^{-1}$ ) to biomass $(B ; \mu \mathrm{g}$ AFDW) and water temperature $\left(T_{;}{ }^{\circ} \mathrm{C}\right)$ with $\mathrm{r}^{2}=0.94$. Indirect models for estimating secondary production are more accurate when applied to situations similar to those in which the model was derived (Dolbeth et al. 2005, Cusson et al. 2006), and Edgar's (1990) equation was derived for estuarine macrobenthic species in temperate latitudes, similar to our study. Additionally, he also formulated specific allometric equations for various animal groups (crustaceans, molluscs, and polychaetes), which were used in this study to estimate production for each respective group; the general equation was used for animals that did not fall into one of the 3 aforementioned groups (Table 1). The only departure from Edgar's method, which used the mean AFDW of animals retained on a series of sieves of differing mesh sizes, was the usage of mean AFDW of each species by sample (Rakocinski \& Zapfe 2005). Biomass measurements at the species level allowed for the examination of taxonomic and functional group associations between production and DO.

The theoretical basis for Edgar's (1990) equation is grounded in the metabolic theory of ecology that 
shows, among other things, that a constant fraction of metabolism tends to be allocated to production across taxa (Brown et al. 2004). Edgar's (1990) equation has been used extensively to estimate secondary production of macrobenthos in temperate estuarine environments (e.g. Arias \& Drake 1994, Edgar et al. 1994, Wilber \& Clarke 1998, Bologna \& Heck 2002, Cowles et al. 2009, Douglass et al. 2010, Blake \& Duffy 2012, Rakocinski 2012), and it has been validated to produce similar production estimates when compared with other indirect methods of estimation, or direct production measurements (Arias \& Drake 1994, Wilber \& Clarke 1998, Cowles et al. 2009). To verify the production estimates using Edgar's (1990) allometric equation in Chesapeake Bay, Hagy (2002) compared the structure and prediction of the Edgar (1990) model to the Tumbiolo \& Downing (1994) model, which predicts annual macrobenthic production from depth, annual mean biomass, and water temperature. Hagy (2002) found little to no difference between the 2 models. Further, Blumenshine \& Kemp (2000) validated the accuracy of the Tumbiolo \& Downing (1994) model against direct calculations of production in Chesapeake Bay (Holland et al. 1988). Given the close agreement between the Tumbiolo \& Downing (1994) model and Edgar (1990) model, the Edgar (1990) model was selected based on its more appropriate time-step (e.g. seasonal production rather than annual mean production).

\section{Data analysis}

A repeated-measures ANOVA was conducted on the seasonal replicate data for 2007 and 2008 to determine the variance in production among 4 seasons (spring, summer, fall, and the following spring). The model included year as a factor with the randomly selected sites as the repeated measures, and the varying season as the treatment. The physical parameters DO concentration, salinity, and \% silt/clay were covariates. Normality was checked with the Shapiro-Wilk test, and homogeneity of variance with Bartlett's test. Non-normal data was log transformed. Tukey's HSD test was used for multiple mean comparisons (Zar 1999).

In an information-theoretic approach, general linear models (GLM) were posed, using residual sums of squares (RSS) estimates to determine Akaike's information criterion (AIC) for our seasonal replicate data. AIC is a measure of the explanatory power of a statistical model that accounts for the number of parameters in the model. The RSS (derived from the re- peated-measures analysis) of the estimated model parameter $(\theta)$ was determined given the data (Gotelli \& Ellison 2004), and this approach determined the model that optimized goodness of fit and best reflected effects on macrobenthic production. When comparing among multiple models for the same phenomenon, the model with the lowest AIC value was considered to be the best model. For this study, corrected $\mathrm{AIC}\left(\mathrm{AIC}_{\mathrm{c}}\right)$, a second-order bias correction necessary for small samples (Burnham \& Anderson 2002), was used to determine model strength. $\mathrm{AIC}_{\mathrm{c}}$ values were then used to determine AIC differences $\left(\Delta_{i}\right)$, relative to the smallest $\mathrm{AIC}_{\mathrm{c}}$ value in the set of tested models. Hence, $\Delta_{i}$ rescaled $\mathrm{AIC}_{\mathrm{c}}$ values such that the model with the minimum $\mathrm{AIC}_{\mathrm{c}}$ value had a $\Delta_{i}=0$. Derived $\Delta_{i}$ values were used to determine Akaike weights $\left(w_{i}\right)$. The $w_{i}$ summed to 1 , and were interpreted as the probability that model $i$ was the expected best model for the sampling situation considered. If a 'best' model could not be determined, model averaging was conducted. Model-averaged estimates for the measured variables are derived from the sum of the $\beta$ estimates multiplied by the $w_{i r}$ for all models. Instead of using only those models with a lot of support, all models were used in model averaging to ensure the $w_{i}$ summed to 1 . This is an appropriate method of model averaging, as models with little or no support essentially get ignored in the calculation, i.e. they are weighted very little (Burnham \& Anderson 2002). Sturdivant (2011) determined that DO concentration, salinity, and grain size had significant relationships with macrobenthic production in Chesapeake Bay; thus, the 7 models constructed in this paper used those parameters and were hierarchically based on those findings (Table 2).

For the continuous-monitoring data, paired $t$-tests were used to determine differences in macrobenthic

Table 2. Parameters for the general linear models $\left(g_{x}\right)$, corresponding to the different hypotheses concerning the effects on macrobenthic production (response = macrobenthic production $=\theta$ ). $k=$ number of parameters, including $\sigma^{2}$ as a parameter. $\mathrm{DO}=$ dissolved oxygen

\begin{tabular}{|lccccc|}
\hline Model & $k$ & $\begin{array}{c}\alpha \\
\text { constant }\end{array}$ & $\begin{array}{c}x_{1} \\
\text { DO }\end{array}$ & $\begin{array}{c}x_{2} \\
\text { salinity }\end{array}$ & $\begin{array}{c}x_{3} \\
\text { grain size }\end{array}$ \\
\hline$g_{1}$ & 3 & $\alpha$ & $\beta 1$ & & \\
$g_{2}$ & 3 & $\alpha$ & & $\beta 2$ & \\
$g_{3}$ & 3 & $\alpha$ & & & $\beta 3$ \\
$g_{4}$ & 4 & $\alpha$ & $\beta 1$ & $\beta 2$ & $\beta 3$ \\
$g_{5}$ & 4 & $\alpha$ & $\beta 1$ & & $\beta 3$ \\
$g_{6}$ & 4 & $\alpha$ & & $\beta 2$ & $\beta 3$ \\
$g_{7}$ & 5 & $\alpha$ & $\beta 1$ & $\beta 2$ & $\beta 3$ \\
\hline
\end{tabular}


production between sites for each year, and to validate differences (or the lack of) in the physical parameters at the hypoxic and normoxic sites. Regression analysis was conducted to determine correlations between DO concentration and macrobenthic production for the continuous-monitoring data. ANOVA was used to assess production differences between the functional groups mobility and feeding type due to $>2$ functional types for both the mobility and feeding type functional groups. Using taxonomic identification and biomass measurements from samples collected in 2007 and 2008, mean estimations of sediment reworking rates (SRR) were calculated from values reported in Diaz \& Schaffner (1990). SRR is analogous to bioturbation, the biological reworking of sediments (Meysman et al. 2006). Mean estimations of SRR (in mg DW sed $_{\text {ind. }}{ }^{-1} \mathrm{~d}^{-1}$ ) were compared for normoxic and hypoxic sites in 2007 and 2008 using a paired $t$-test. All statistical analyses were conducted using R Statistical software; means are presented with standard deviations unless otherwise noted.

\section{RESULTS}

The RSS for each of the 7 models (Table 2) were used to generate the $\mathrm{AIC}_{c}$ results (Table 3). Based on the calculated Akaike weights, model $g_{1}$ (which included DO alone) had the highest $w_{i}$, while models $g_{2}$ (salinity), $g_{3}$ (\% silt and clay), $g_{4}$ (DO and salinity), and $g_{7}$ (DO, salinity, and \% silt and clay) were equally plausible (i.e. had a $w_{i} \geq 0.10$ ). However, overwhelming evidence for a single superior model, indicated by a $w_{i} \geq 0.90$ (Burnham \& Anderson 2002), did not exist. To better clarify which variable (DO, salinity, or grain size) was most important to our esti-

Table 3. Constructed Akaike's information criterion (AIC) table displaying results of each model (models are defined in Table 2); $k=$ the number of parameters with error as a parameter, RSS $=$ residual sums of squares, $\mathrm{AIC}_{\mathrm{c}}=$ corrected Akaike's information criterion, $\Delta_{i}=$ AIC differences relative to the smallest $\mathrm{AIC}_{\mathrm{c}}$ value, $w_{i}=$ Akaike weights

\begin{tabular}{|lccccc|}
\hline Model & $k$ & RSS & AIC $_{\mathrm{c}}$ & $\Delta_{i}$ & $w_{i}$ \\
\hline$g_{1}$ & 3 & 35950168 & 244.8 & 0.00 & 0.30 \\
$g_{2}$ & 3 & 40128749 & 246.7 & 1.91 & 0.11 \\
$g_{3}$ & 3 & 39611986 & 246.5 & 1.69 & 0.13 \\
$g_{4}$ & 4 & 31561010 & 245.0 & 0.21 & 0.27 \\
$g_{5}$ & 4 & 39258209 & 248.8 & 4.01 & 0.04 \\
$g_{6}$ & 4 & 39349502 & 248.9 & 4.05 & 0.04 \\
$g_{7}$ & 5 & 29958470 & 246.7 & 1.93 & 0.11 \\
\hline
\end{tabular}

mated parameter (macrobenthic production), for each variable the $w_{i}$ were summed from each model containing one of the aforementioned variables. Summed $w_{i}$ were as follows: DO $=0.72$, salinity $=$ 0.53 , and \% silt and clay $=0.32$, indicating DO was the most important of the 3 measured variables, but strong evidence existed for the importance of salinity as well. Given the strong support for a number of models and the parity in importance between 2 of the 3 measured variables, model averaging was employed for all models. Based on model-averaged results (Table 4), DO concentration and salinity had the most impact on macrobenthic production during 2007 and 2008 in the lower Rappahannock River. For each $1 \mathrm{mg} \mathrm{l}^{-1}$ increase in DO concentration, the rate of macrobenthic production increased by $27.6 \mathrm{mg} \mathrm{C}$ $\mathrm{m}^{-2} \mathrm{~d}^{-1}$, and it increased by $15.6 \mathrm{mg} \mathrm{C} \mathrm{m}^{-2} \mathrm{~d}^{-1}$ per psu decrease of salinity. Percent silt and clay had a marginal effect on macrobenthic production, increasing the rate of production by $3.1 \mathrm{mg} \mathrm{C} \mathrm{m}^{-2} \mathrm{~d}^{-1}$ per percentage point increase in \% silt and clay. Mean salinity of all sampling sites over our study period was $14.3 \pm 2.6 \mathrm{psu}$, indicating little variation in salinity, and mean $\%$ silt and clay across all samples during our study period was $61.2 \pm 12.2 \%$.

Macrobenthic production differed among seasons (Fig. 2), with the highest rate in the 1st spring (2007). Compared with 1st spring, the 2007 summer macrobenthic production was lower by $\sim 90 \%$, and overall, the lowest observed. In the fall, macrobenthic production was higher than the summer by $\sim 70 \%$. Macrobenthic production in the 2nd spring was approximately equal to the fall but did not parallel the 1st spring. A similar trend was observed in the 2008 sampling. The 1st spring was the highest overall and summer the lowest, $\sim 80 \%$ lower than 1 st spring. Fall macrobenthic production in 2008 was $\sim 70 \%$ higher than summer, but not as high as 1 st spring, and 2nd spring production was substantially lower than the 1st spring. In both years, there was high variability in the 1 st spring and low variability in the summer.

Table 4. Model averaged estimates for the 3 measured variables including dissolved oxygen, salinity, \% silt and clay. $\beta_{j}$ denotes the estimator of $\beta$ based on model $g_{i i}$ SE denotes the standard error

\begin{tabular}{|lcc|}
\hline Variable & $\beta_{j}$ & SE \\
\hline Dissolved oxygen & 27.6 & 22.9 \\
Salinity & -15.6 & 16.8 \\
$\%$ silt and clay & 3.1 & 2.0 \\
\hline
\end{tabular}



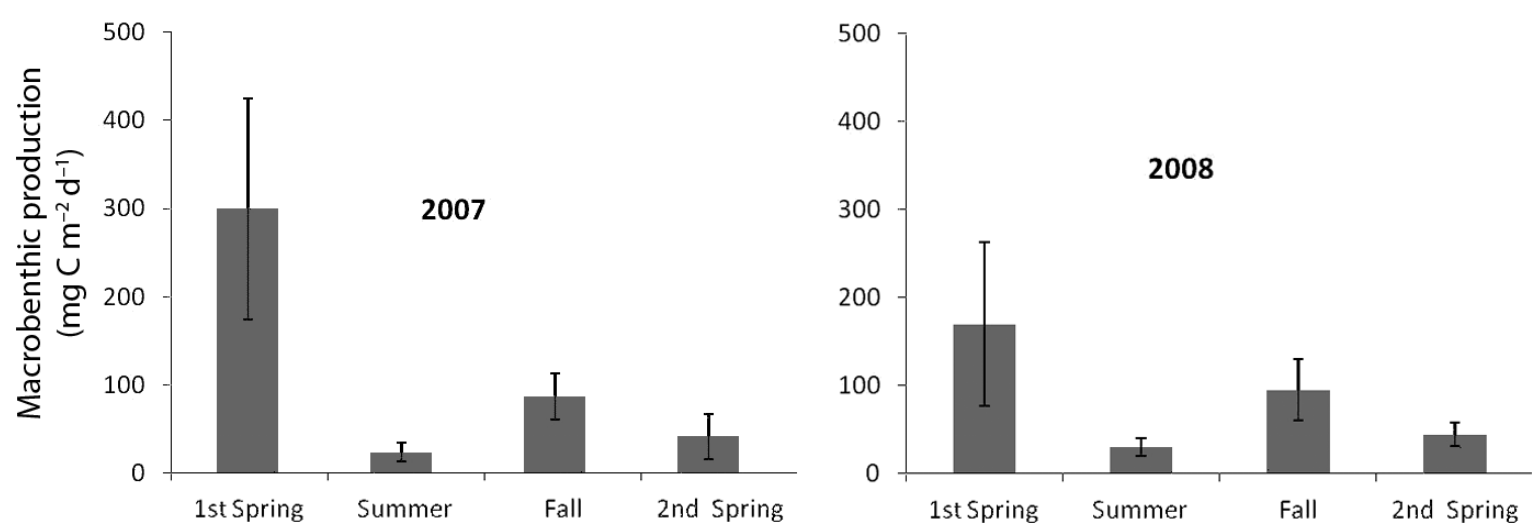

Fig. 2. Mean daily macrobenthic production by year and season. Samples were collected during the 1st spring, summer, fall, and 2nd spring between spring 2007 and spring 2009. Error bars represent $\pm 1 \mathrm{SE}_{;} \mathrm{n}=10$ for each season by year treatment (i.e. 1st spring $\mathrm{n}=10$ ) for a total $\mathrm{N}=80$

DO measurements collected by datasondes at each of the continuously monitored sites from 2007 (Sites 18 and 25) and 2008 (Sites 11 and 12) were compared to corresponding point measurements of DO using a paired $t$-test to validate the accuracy of datasonde readings (Fig. 3). There was no significant difference between corresponding datasonde readings and point DO measurements for any of the 4 sites, provid-

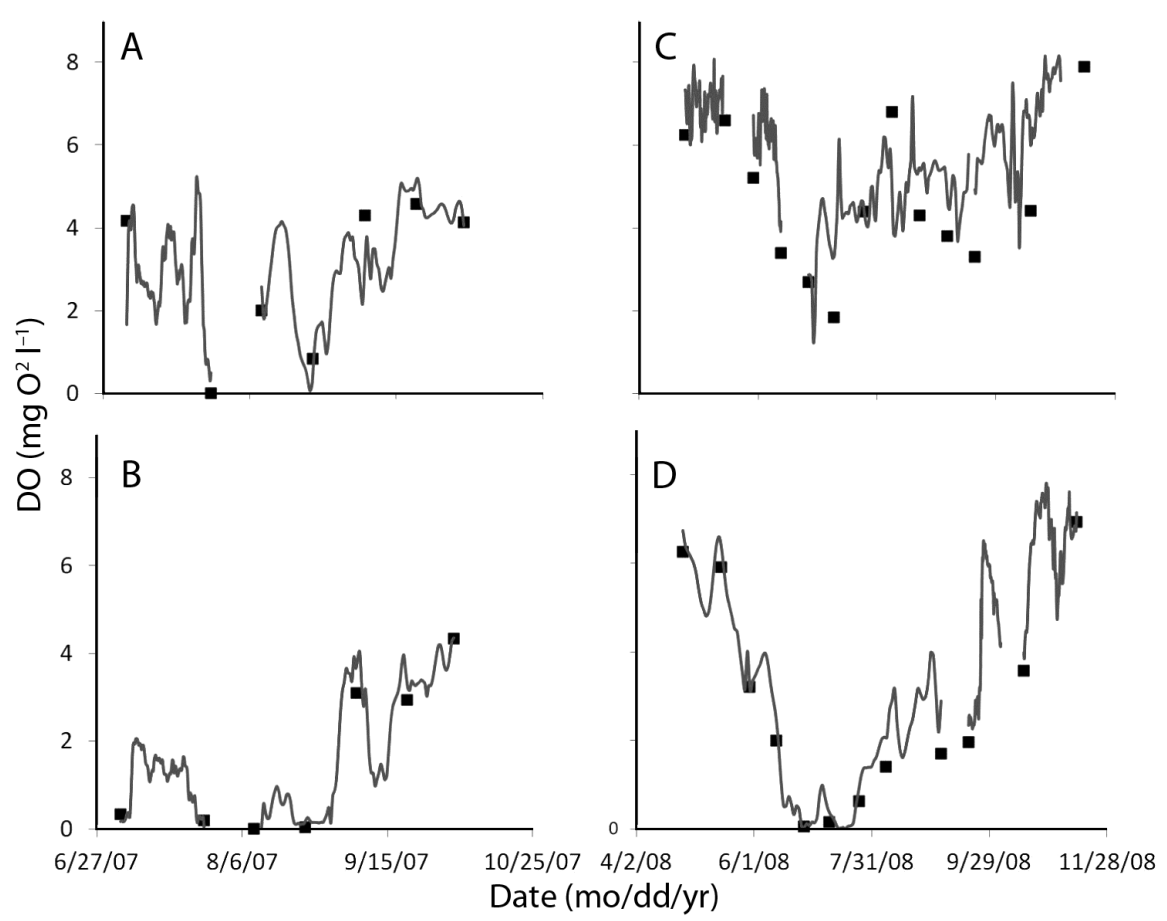

Fig. 3. Dissolved oxygen (DO) concentration data for each of the 4 continuously monitored sites (gray line), compared to corresponding point DO measurements (black squares). No significant differences between datasonde readings and corresponding point DO measurements for (A) the 2007 normoxic Site 25 (df $=6, T=$ $-0.97, p=0.377)$, (B) the 2007 hypoxic Site $18(\mathrm{df}=6, T=0.22, \mathrm{p}=0.834),(\mathrm{C})$ the 2008 normoxic Site $12(\mathrm{df}=12, T=0.51, \mathrm{p}=0.62)$ and (D) the 2008 hypoxic Site 11 $(\mathrm{df}=12, T=0.18, \mathrm{p}=0.89)$. Gaps in data represent time periods when data was not collected due to datasonde malfunction ing confidence in our DO concentration data. In 2007, $55 \%$ of the observed DO measurements at hypoxic Site 18 were hypoxic, compared to less than $20 \%$ at normoxic Site 25. Note that in 2007, the nominally normoxic Site 25 (Fig. 3A) was not a true normoxic site as it experienced short durations of hypoxia on several occasions; this assessment does not include the considerable data gap for the time when Site 25 was under hypoxic conditions, which would have increased the hypoxic percentage assessment for Site 25. In 2008, $45 \%$ of the observed DO measurements at hypoxic Site 11 were hypoxic with $15 \%$ of the observed DO at anoxic levels. At normoxic Site 12, less than $2 \%$ of DO measurements were hypoxic.

There was no significant difference in salinity, temperature, or $\%$ silt and clay between our continuously monitored normoxic and hypoxic sites in 2007 or 2008 (Table 5). Depth was significantly different between the normoxic and hypoxic sites in 2007 and 2008, however, depth, when factored in with salinity, \% silt and clay, and temperature, had no significant effect on daily macrobenthic production in Chesapeake Bay or its tributaries (Sturdivant 2011). Therefore, with similar physical parameters between the normoxic and hypoxic sites for both years, macrobenthic production was regressed against only 
Table 5. Statistical comparison, using paired $t$-tests, of physical data from the continuously monitored (A) 2007 sites, hypoxic Site 18 (Hyp) and normoxic Site 25 (Norm); and (B) 2008 sites, hypoxic Site 11 (Hyp) and normoxic Site 12 (Norm). Depth was the only physical parameter that was significantly different

\begin{tabular}{|lccccc|}
\hline $\begin{array}{l}\text { A) } \\
\text { Parameter }\end{array}$ & $\begin{array}{c}\text { Site 18 } \\
\text { (hyp) }\end{array}$ & $\begin{array}{c}\text { Site 25 } \\
\text { (norm) }\end{array}$ & df & $T$ & $\mathrm{p}$ \\
\hline Temp $\left({ }^{\circ} \mathrm{C}\right)$ & 25.8 & 26.0 & 6 & -0.6 & 0.54 \\
Salinity (psu) & 18.6 & 17.9 & 6 & 1.4 & 0.20 \\
$\%$ silt and clay & 89.8 & 90.0 & 6 & -0.4 & 0.67 \\
Depth (m) & 10.6 & 9.6 & 6 & 11.1 & $<0.0005$ \\
& & & & & \\
B) & & & & & \\
Parameter & Site 11 & Site 12 & df & $T$ & p \\
& (hyp) & (norm) & & & \\
\hline Temp ( $\left.{ }^{\circ} \mathrm{C}\right)$ & 21.8 & 22.2 & 12 & -2.1 & 0.06 \\
Salinity (psu) & 14.5 & 14.8 & 12 & -0.7 & 0.48 \\
$\%$ silt and clay & 98.4 & 94.2 & 12 & 1.8 & 0.05 \\
Depth (m) & 9.8 & 7.7 & 12 & 10.6 & $<0.0005$ \\
\hline
\end{tabular}

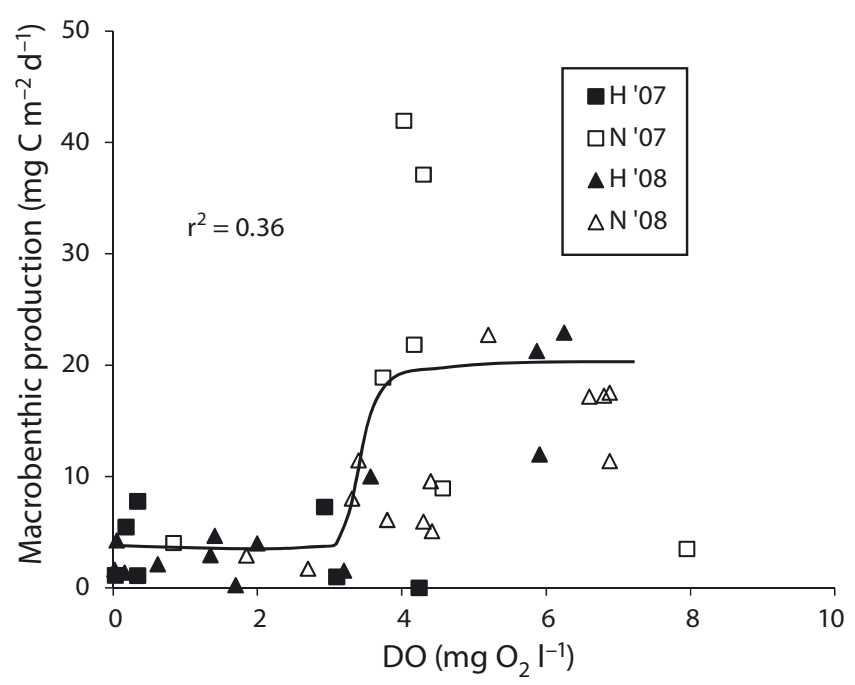

Fig. 4. Dissolved oxygen concentration and daily macrobenthic production for the continuously monitored hypoxic and normoxic sites in 2007 and 2008. There was a sigmoid relationship between DO and daily macrobenthic production (df $=39, F=10.31, p=0.0003)$. Squares represent 2007 data; triangles represent 2008 data. Solid symbols indicate the hypoxic $(\mathrm{H})$ sites, and hollow symbols the normoxic $(\mathrm{N})$ sites

DO concentration (Fig. 4). There was a sigmoid relationship between daily macrobenthic production and DO concentration; macrobenthic production was low in DO concentrations below $\sim 3.0 \mathrm{mg} \mathrm{O}_{2} \mathrm{l}^{-1}$, rising greater than an order of magnitude between 3.0 and $4.0 \mathrm{mg} \mathrm{O} \mathrm{O}_{2} \mathrm{l}^{-1}$. Macrobenthic production was also more variable at higher DO concentrations; the standard error (SE) of mean macrobenthic production at normoxic DO concentrations $\left(>2.8 \mathrm{mg} \mathrm{O}_{2} \mathrm{l}^{-1}\right.$ ) was 2.2 $\mathrm{mg} \mathrm{C} \mathrm{m} \mathrm{m}^{-2} \mathrm{~d}^{-1}$, compared to a SE of $0.5 \mathrm{mg} \mathrm{C} \mathrm{m}^{-2} \mathrm{~d}^{-1}$ at DO concentrations $\leq 2.8 \mathrm{mg} \mathrm{O}_{2} \mathrm{l}^{-1}$.

The bi-weekly macrobenthic production and community composition between the normoxic and hypoxic sites in 2007 (Sites 25 and 18, respectively) and 2008 (Sites 12 and 11) were compared. Species richness was $\sim 30 \%$ lower at hypoxic Site 18 and $\sim 40 \%$ lower at hypoxic Site 11 compared to normoxic Sites 25 and 12, respectively. In 2007, macrobenthic production at Site 18 was significantly lower than Site 25 (df $=6, T=-2.87, p=0.029$; Fig. 5A); the hypoxic site had on average $85 \%$ lower production than the normoxic site. Hypoxia-resistant species contributed to half of the macrobenthic production at Site 25 , and $\sim 85 \%$ of the macrobenthic production at Site 18 (Table 6). The hypoxia-resistant spionid Paraprionospio pinnata dominated macrobenthic production at Site 18 , contributing to $\sim 78 \%$ of the total macrobenthic production. In 2008, macrobenthic production was not significantly different between Sites 11 and 12, but a trend of higher production at normoxic Site 12 existed (Fig. 5B). Site 11 had on average $36 \%$ lower production than Site 12, but this assessment included early spring, a time period unaffected by hypoxia, and when macrobenthic production was approximately equal at both sites. Mean macrobenthic production at Sites 11 and 12 between 25 April 2008 and 12 November 2008 was not significantly different ( $\mathrm{df}=12, T=-2.11, \mathrm{p}=0.056$ ), at approximately 6.8 and $10.5 \mathrm{mg} \mathrm{C} \mathrm{m} \mathrm{C}^{-1}$, respectively. When the difference in production between these 2 sites was assessed starting at the development of hypoxia and going through until it ended (29 May 2008 to 12 November 2008), the production between the 2 sites was significantly different ( $\mathrm{df}=$ $10, T=2.25, \mathrm{p}=0.049$ ), with macrobenthic production $\sim 50 \%$ lower at Site 11 compared to Site 12 during this time period. Mean production during this period was 4.7 and $8.9 \mathrm{mg} \mathrm{C} \mathrm{m}^{-2} \mathrm{~d}^{-1}$ at Sites 11 and 12 , respectively. Overall, $P$. pinnata contributed to more than half of the observed macrobenthic production at the hypoxic site compared to only $\sim 30 \%$ of macrobenthic production at the normoxic site in 2008.

In 2007 and 2008, there were no significant differences in macrobenthic production when tested by the functional groups of mobility or feeding types ( $p>0.05)$, due to large variances observed in these groups. There were significant differences in mean estimates of SRR by site (Fig. 6). In 2007, macrobenthos at the normoxic site reworked an estimated $19600 \mathrm{mg} \mathrm{DW}_{\text {sed }}$ ind. $^{-1} \mathrm{~d}^{-1}$, which was significantly 
A) 2008

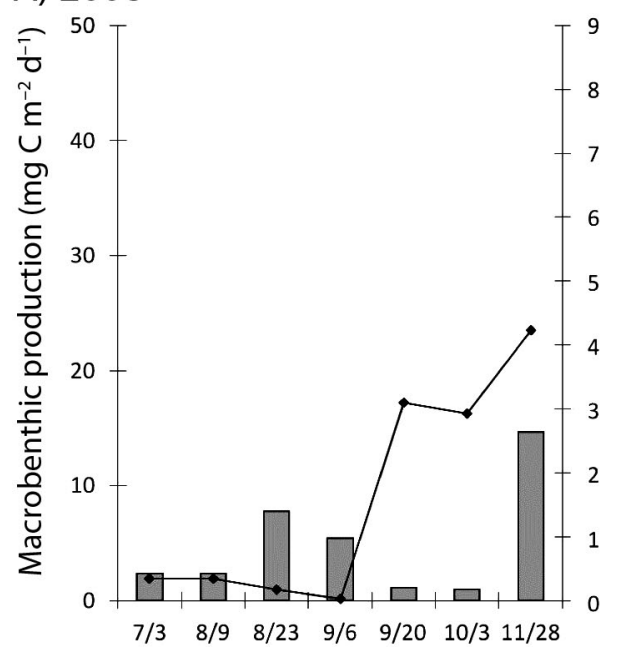

\section{B) 2008}

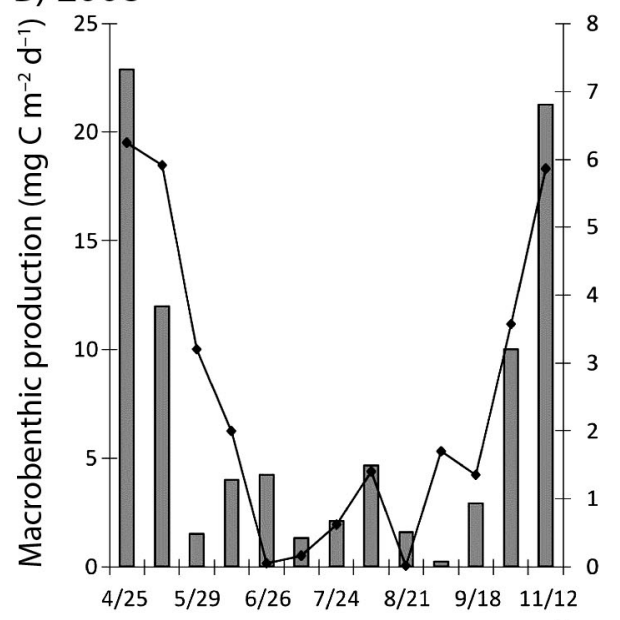

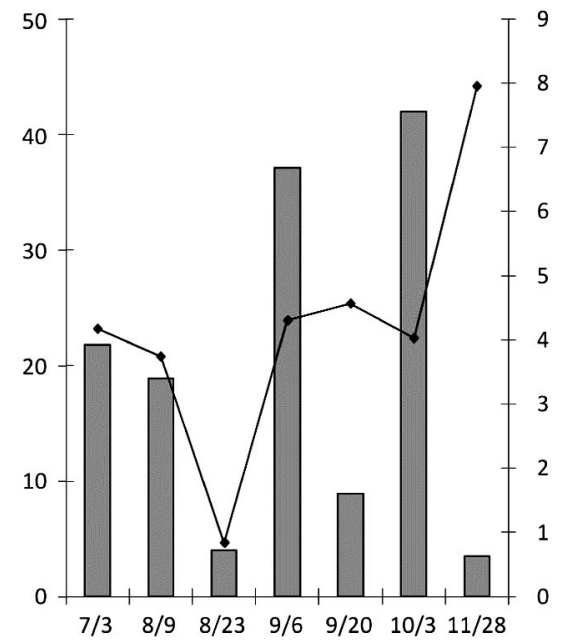

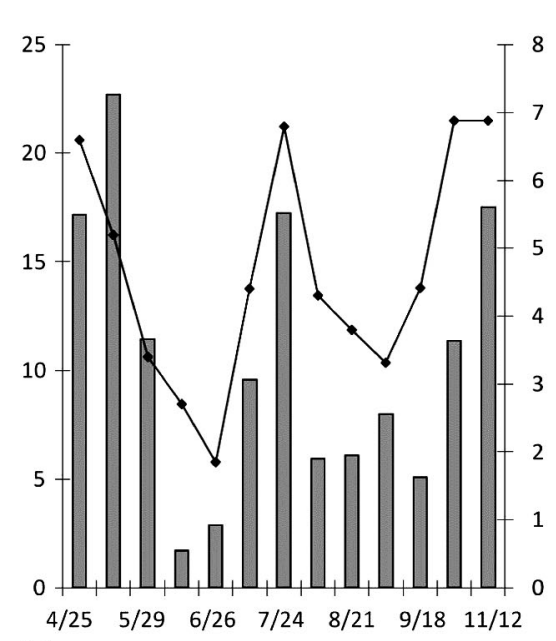

Date $(\mathrm{mo} / \mathrm{d})$

Fig. 5. Daily macrobenthic production (gray bars, left yaxis) and corresponding DO concentration (black line, right y-axis) for (A) hypoxic Site 18 and normoxic Site 25 in 2007; and (B) hypoxic Site 11 and normoxic Site 12 in 2008. In 2007, macrobenthic production was significantly different between Sites 18 and $25(\mathrm{df}=6, T=-2.87, \mathrm{p}=$ 0.029), and in 2008 macrobenthic production was not significantly different between Sites 11 and 12 (df = 12, $T=-2.11, p=0.056)$. Data was used to derive sigmoid relationship in Fig. 4. Note different scale between years higher than SRR of $2200 \mathrm{mg} \mathrm{DW}_{\text {sed }}$ ind. $^{-1} \mathrm{~d}^{-1}$ estimated at the hypoxic site. A similar trend was observed in 2008: the normoxic site had significantly higher estimates of SRR at $5200 \mathrm{mg} \mathrm{DW}_{\text {sed }}$ ind. ${ }^{-1} \mathrm{~d}^{-1}$, compared to the estimates of $800 \mathrm{mg} \mathrm{DW}_{\text {sed }}$ ind. ${ }^{-1} \mathrm{~d}^{-1}$ at the hypoxic site. The higher estimates of SRR at the normoxic sites were driven by the biomass of Loimia medusa, Acteocina canaliculata, and Heteromastus filiformis - species with high burrowing rates (Diaz \& Schaffner 1990).

\section{DISCUSSION}

DO concentration had a measureable correlation with macrobenthic production in the Rappahannock River estuary; production was low below $\sim 3 \mathrm{mg} \mathrm{O}_{2}$ $1^{-1}$, and rose an order of magnitude between 3 and
$4 \mathrm{mg} \mathrm{O} \mathrm{O}_{2} \mathrm{l}^{-1}$. Seitz et al. (2009) documented similar results, finding sigmoid relationships between macrobenthic biomass and DO concentration in varying salinity regimes of Chesapeake Bay, with a threshold around $3 \mathrm{mg} \mathrm{l}^{-1}$ for polyhaline regions. The negative impacts of hypoxia on macrobenthic community structure are well documented (Diaz \& Rosenberg 1995, Vaquer-Sunyer \& Duarte 2008, Van Colen et al. 2010), and our results indicate hypoxia has equally negative effects on macrobenthic production. It is unclear whether the observed relationship between DO concentration and macrobenthic production is due to direct or indirect mechanisms. A lack of DO in bottom waters can cause direct mortality via asphyxiation (Diaz \& Rosenberg 1995) and inhibit macrobenthic recruitment and growth, hampering production (Forbes \& Lopez 1990, Powers et al. 2001); yet the impact of hypoxia on macrobenthos extends 
Table 6. Compilation of the major hypoxia resistant species collected at the 4 continuously monitored sites: in 2007 , hypoxic Site 18 (hyp) and normoxic Site 25 (norm); in 2008, hypoxic Site 11 (hyp) and normoxic Site 12 (norm). Values in the table represent the percentage of macrobenthic production contributed by each species by site; abundances are in parentheses and dash denotes no data. For taxon group: $\mathrm{A}=$ annelid, $\mathrm{B}=$ bivalve

\begin{tabular}{|c|c|c|c|c|c|c|}
\hline Taxon (group) & $\begin{array}{l}\text { Hypoxia } \\
\mathrm{LT}_{50}(\mathrm{~h})\end{array}$ & $\begin{array}{l}\text { Site } 18 \\
\text { (hyp) }\end{array}$ & $\begin{array}{l}\text { Site } 25 \\
\text { (norm) }\end{array}$ & $\begin{array}{l}\text { Site } 11 \\
\text { (hyp) }\end{array}$ & $\begin{array}{l}\text { Site } 12 \\
\text { (norm) }\end{array}$ & Source \\
\hline Heteromastus filiformis (A) & $168-312$ & - & $0.1(32)$ & $3.3(12)$ & $0.1(1)$ & $\begin{array}{l}\text { Rosenberg (1972), Warren (1976), } \\
\text { Kravitz (1983) }\end{array}$ \\
\hline Loimia medusa (A) & $72-113$ & $0.8(2)$ & $1.8(3)$ & - & $1.2(1)$ & Breitburg et al. (2003) \\
\hline Macoma balthica (B) & $212-1658$ & $2.1(2)$ & - & - & - & $\begin{array}{l}\text { Aller et al. (1983), Brafield \& Newell (1961), } \\
\text { Hines \& Comtois (1985) }\end{array}$ \\
\hline Nereis succinea (A) & $62-84$ & $0.8(1)$ & $0.1(1)$ & $27.5(20)$ & $28.7(17)$ & $\begin{array}{l}\text { Fauchald \& Jumars (1979), Kravitz (1983), } \\
\text { Hines \& Comtois (1985), Fong (1991), } \\
\text { Sagasti et al. (2001) }\end{array}$ \\
\hline Paraprionospio pinnata (A) & - & $77.5(48)$ & $47(79)$ & $52.2(52)$ & $33.6(50)$ & $\begin{array}{l}\text { Dauer et al. (1981), Kravitz (1983), } \\
\text { Schaffner (1987) }\end{array}$ \\
\hline Streblospio benedicti (A) & 43 & $1.3(2)$ & $1.4(11)$ & $3.6(12)$ & $3.5(19)$ & $\begin{array}{l}\text { Dauer et al. (1981), Hines \& Comtois (1985), } \\
\text { Kravitz (1983), Llansó (1991) }\end{array}$ \\
\hline Tubificoides spp. (A) & 720 & $1.3(3)$ & - & - & $0.3(3)$ & $\begin{array}{l}\text { Tevesz et al. (1980), Hines \& Comtois (1985), } \\
\text { Giere et al. (1999) }\end{array}$ \\
\hline
\end{tabular}
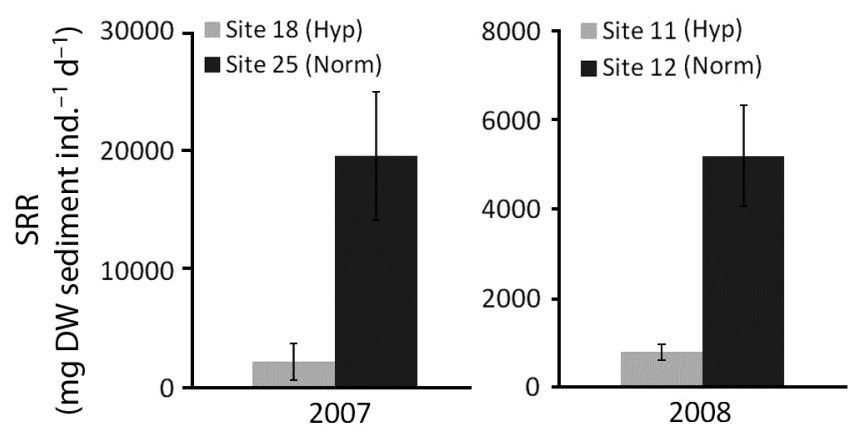

Fig. 6. Estimated sediment reworking rates $\left(\mathrm{SRR}, \mathrm{mg} \mathrm{DW}_{\text {sed }}\right.$ ind. ${ }^{-1} \mathrm{~d}^{-1}$ ) by sampling year and site. Normoxic sites in 2007 and 2008 had higher mean estimations of SRR when compared to hypoxic sites. In 2007, normoxic Site 25 and hypoxic Site 18 had significantly different mean estimations of SRR ( $\mathrm{df}=6, T=-3.90, \mathrm{p}=0.008$ ). In 2008, normoxic Site 12 and hypoxic Site 11 had significantly different mean estimations of SRR ( $d f=12, T=-3.55, p=0.004$ ). Error bars represents $\pm 1 \mathrm{SE}$

further. At the development of hypoxia, sessile organisms such as macrobenthos decrease feeding and movement (Riedel et al. 2008) in an attempt to depress their metabolism. If the organisms are able to avoid mortality via asphyxiation, such actions during prolonged hypoxic events could indirectly lead to starvation (Diaz \& Rosenberg 1995). Additionally, during severe hypoxia and anoxia, sulfate $\left(\mathrm{SO}_{4}\right)$ is reduced to sulfide $\left(\mathrm{H}_{2} \mathrm{~S}\right)$, a toxic compound documented to contribute to macrobenthic mortality
(Llansó 1991, Shumway et al. 1993, Vaquer-Sunyer \& Duarte 2010) through inhibition of the electron transport chain in aerobic respiration (Torrans \& Clemens 1982) by binding to cytochrome $c$ oxidase resulting in chemical asphyxiation of cells (Bagarinao 1992, Collman et al. 2009). Predation is another factor possibly contributing to lowered production during hypoxia. Macrobenthos migrate upwards in the sediment during hypoxia to avoid low DO and sulfide toxicity (Sturdivant et al. 2012), and can breach and extend their bodies and appendages above the sediment surface, increasing susceptibility to predation (Pihl et al. 1992, Nestlerode \& Diaz 1998, Long \& Seitz 2008); though in some cases prey gain refuge from their less-tolerant predators under hypoxia due to predation inefficiency or predator exclusion (Brante \& Hughes 2001, Altieri 2008).

Macrobenthic production in the lower Rappahannock River was variable between seasons in both 2007 and 2008. Spring is a productive time of year in coastal estuaries as nutrient input from spring freshets enriches shallow systems (Boynton et al. 1995, Magnien et al. 1995) concurrent with recruitment of many benthic organisms (Simon 1967, Sandifer 1972). The shallow nature of Chesapeake Bay fosters tight benthic-pelagic coupling, and water column productivity reaches the bottom through turbulent mixing and subsequent suspension feeding (Cloern 2001) or direct sedimentation (Davies \& Payne 1984), thus fueling benthic production. Hypoxia is pervasive in Chesapeake Bay and its tributaries dur- 
ing the summer months (Kuo et al. 1991, Hagy et al. 2004) and, as shown in this study, could account for the lower production observed during the summer via the direct or indirect mechanisms discussed in the preceding paragraph. Production only partially recovered in the fall, though this is not surprising. In the colder months, a lack of nutrient input that normally fuels spring production (Hagy et al. 2005), altered hydrography that mixes plankton below the critical depth (Jackson 2008), and lower temperatures reducing metabolism (Diaz \& Schaffner 1990) all contribute to reduced productivity. However, the lack of recovery of macrobenthic production in the 2nd spring indicates a possibility of carry-over effects from the previous year. Lost production in hypoxic sites may negatively impact overall macrobenthic recruitment. Macrobenthos employ 2 nutritional recruitment strategies, planktotrophy and/or lecithotrophy (Levin et al. 1987), which have consequences for dispersal distance and population size (Thorson 1950, Kempf \& Hadfield 1985). Planktotrophic development usually involves production of a larger number of smaller ova than lecithotrophic development, and because planktotrophic larvae are smaller and must feed in the water column, they spend more time in their larval phase before settlement, allowing for greater dispersal (Reed et al. 2000). Neither nutritional strategy guarantees increased settlement success (Levin \& Huggett 1990); macrobenthic larval settlement is not purely random but selective (Watzin 1986). The dispersing larvae are responsible for recognizing the habitat that is optimal for survival and reproduction of the more sedentary adult forms (Chia \& Rice 1978, Butman et al. 1988), and this process can be influenced by hydrodynamic processes, chemical induction, and suitability of respective substrate (Butman et al. 1988, Levin 2006, Koehl \& Hadfield 2010). In addition, changes in macrobenthic community composition (discussed below) may affect larval recruitment, and subsequently production.

Macrobenthic production was as much as $85 \%$ lower at hypoxic sites, but the fate of the 'lost' production remains unknown. The simplest response is that it was never produced. Habitats that are exposed to extensive hypoxia and anoxia have low annual biomass and production (Rainer 1982, Levin 2003, Seitz et al. 2009). Macrobenthic production in areas that experience prolonged hypoxia is regulated by the amount of benthic recruitment and growth that occurs during periods of normoxia (Nichols 1977); therefore, the production at these sites is limited by productivity during normoxia. The lower production observed at hypoxic sites would thus not be a func- tion of its removal, but rather that it was never created. Alternatively the 'lost' production could have been transferred to higher trophic levels, as hypoxia can enhance predation when predators capitalize on stressed prey (Seitz et al. 2003, Eggleston et al. 2005, Long \& Seitz 2008), although severe hypoxia inhibits predation (Altieri 2008) and disrupts the normal energy flow to higher consumers (Baird et al. 2004). Moreover, severe prolonged hypoxia could alternatively allow for the microbial community, which can utilize other compounds as electron acceptors $\left(\mathrm{NO}_{3}{ }^{-}\right.$, $\mathrm{MnO}_{4}, \mathrm{FeOH}, \mathrm{SO}_{4}{ }^{2-}$, and $\mathrm{CO}_{2}$ ) when DO is absent, to process macrobenthic production through the microbial food web (Baird et al. 2004). A combination of these processes is likely responsible for the lowered production at hypoxic sites. During even short spells (on the order of a week) of hypoxia, the benthic environment of the Rappahannock River becomes microbially dominated (Sturdivant et al. 2012). Additionally, the relatively small spatial extent and lack of sustained severe hypoxia may allow for predators to capitalize on stressed macrobenthos (Llansó 1990, Pihl et al. 1992, Nestlerode \& Diaz 1998.

Functionally, there were no significant differences in the production of feeding or mobility groups for macrobenthos at hypoxic vs. normoxic sites. This was driven by large variances in both types of groups, suggesting that hypoxia may affect the production of these functional groups equally; SRR were, however, significantly related to DO concentrations. Through the bioturbative process of sediment reworking, macrobenthos influence sediment geochemical and physical properties (Lohrer et al. 2004) increasing the quality of marine sediments. Hypoxia can negatively influence bioturbation (Sturdivant et al. 2012); the consequences of lowered rates of bioturbation include decreases in sediment permeability, remineralization, nutrient flux (Lohrer et al. 2004), and a shallower sediment oxic layer (Solan \& Kennedy 2002). DO penetrates sediments by physical diffusion to only a few millimeters below the sediment surface (Revsbech et al. 1980), but bioturbation can distribute DO much deeper in the sediment (Aller 1982).

The spionid Paraprionospio pinnata dominated macrobenthic production at hypoxic sites in both years. $P$. pinnata is an opportunistic species that is morphologically adapted to tolerate a low oxygen environment, having elongated, proliferated, and numerous branchia (Dauer 1985, Lamont \& Gage 2000). In addition to dominating production because of its stress tolerance, P. pinnata may have also benefited from less competition through reduction of other species during hypoxia (Seitz et al. 2009). In our study, species rich- 
ness was $40 \%$ lower at hypoxic sites, potentially decreasing competitive pressure and allowing $P$. pinnata to capitalize on the organic-rich environment that generally accompanies eutrophication-induced coastal hypoxic areas (Pearson \& Rosenberg 1978, Lu \& Wu 1998). While hypoxic sites were dominated by $P$. pinnata, the production at normoxic sites was characterized by species with high SRR, such as Loimia medusa, Acteocina canaliculata, and Heteromastus filiformis. These species were notably absent at the hypoxic sites and contributed to the significant difference in SRR between normoxic and hypoxic sites. Species with life history traits that require high energy demands, such as burrowing to consume food or in search of prey, would be less adapted to an environment where metabolic depression is important to survival, such as in low oxygen environments (Levin 2003).

In our study, salinity and \% silt and clay varied in their effects on macrobenthic production. In a previous study, there was a marginally significant positive relationship between macrobenthic production and \% silt and clay and a significant negative relationship between macrobenthic production and salinity in Chesapeake Bay (Sturdivant 2011). Results from our study corroborated these findings; macrobenthic production increased $3.1 \mathrm{mg} \mathrm{C} \mathrm{m}^{-2}$ $\mathrm{d}^{-1}$ per unit increase in \% silt and clay, and increased $15.6 \mathrm{mg} \mathrm{C} \mathrm{m} \mathrm{C}^{-1}$ per unit decrease in salinity. In estuaries worldwide, salinity is the major governing factor in organism distribution (Perkins 1974, Diaz \& Schaffner 1990, Telesh \& Khlebovich 2010). This study was designed to assess changes in macrobenthic production in a defined upper-mesohaline salinity range of the lower Rappahannock River, thus encompassing a small range of salinity with a mean salinity of 14.3 \pm 2.6 psu. Had our study encompassed a larger salinity range, impacts on macrobenthic production may have been greater. On a total area basis, macrobenthic production is highest in polyhaline habitats and lowest in the euhaline habitats, with the majority of the Bay's macrobenthic production $(\sim 70 \%)$ occurring in high mesohaline and polyhaline habitats (Diaz \& Schaffner 1990). At moderate to high salinities, or when salinity is constant, patterns of benthic distribution are further correlated with sediment type (Dauer et al. 1984, Cooksey \& Hyland 2007). However, \% silt and clay had marginal impacts on macrobenthic production, and this is also likely due to the small spatial extent in which the study took place and the resultant small difference in \% silt and clay among sites; mean \% silt and clay was $61.2 \pm 12.2 \%$.

\section{CONCLUSIONS AND IMPLICATIONS}

Macrobenthic production was related to DO concentration, with macrobenthic production as much as $85 \%$ lower at hypoxic sites. The function of macrobenthic communities changed relative to DO concentration, with hypoxia-resistant spionids dominant during hypoxia and species with high SRR dominant during normoxia. Macrobenthic production differed across seasons, and 2nd spring macrobenthic production may have been impacted by the dynamics of the previous year. Salinity and sediment grain size had significant and marginally significant effects on macrobenthic production, respectively; but given the relatively small spatial extent of the study, DO concentration had the biggest impact on macrobenthic production. The consequences of observed hypoxia impacts on macrobenthic production are troublesome, as previous studies have documented negative cascading effects to higher trophic levels as a result of disturbance to macrobenthic communities (Powers et al. 2005).

There is a general understanding of the relationship between coastal eutrophication and hypoxia, and the consequences for marine fauna. The necessary action required to address the issue in the Bay and its tributaries is simple-reduce nutrient loading (Cloern 2001). Globally, a number of coastal systems that experienced anthropogenic-related hypoxia have shown that when nutrient loading is decreased, water quality increases, chronic hypoxia abates, and many of the associated problems discussed in this paper are mitigated (Kodama et al. 2002, Mee 2005, Diaz et al. 2008). While simple to acknowledge, the implementation of nutrient-reduction policies is far more complicated (Kemp et al. 2005). This is especially true in a system like Chesapeake Bay, where the watershed is impacted by multiple, separately governed states, and where $25 \%$ of the nitrogen input to the system comes from atmospheric deposition (Boynton et al. 1995, Magnien et al. 1995). Though a daunting task for managers, the framework for success in alleviating hypoxia through nutrient reduction is clear.

Acknowledgements. We thank the the editor and 3 anonymous reviewers who helped improve the manuscript, and the staff at Versar and Old Dominion University for data from the Chesapeake Bay Program's Long-term Benthic Monitoring Program. Maryland Department of Natural Resources and Virginia DEQ funded the benthic monitoring program. Supported in part by NOAA grant NA05NOS4781202 to R.J.D., NSF funded Hall-Bonner Fellowship, and NOAA GSP fellowship to S.K.S. This paper is Contribution No. 3307 of the Virginia Institute of Marine Science, College of William \& Mary. 


\section{LITERATURE CITED}

Aller RC (1982) The effects of macrobenthos on chemical properties of marine sediment and overlying water. In: McCall PL, Tevesz MJS (eds) Animal-sediment relationships. New York Plenum, NY, p 53-102

Aller RC, Yingst JY, Ullman WJ (1983) Comparative biogeochemistry of water in intertidal Onuphis (Polychaeta) and Upogebia (Crustacea) burrows: temporal patterns and causes. J Mar Res 41:571-604

Altieri AH (2008) Dead zones enhance key fisheries species by providing predation refuge. Ecology 89:2808-2818

Arias AM, Drake P (1994) Structure and production of the benthic macroinvertebrate community in a shallow lagoon in the Bay of Cadiz. Mar Ecol Prog Ser 115:151-167

Bagarinao T (1992) Sulfide as an environmental-factor and toxicant: tolerance and adaptations in aquatic organisms. Aquat Toxicol 24:21-61

Baird D, Christian RR, Peterson CH, Johnson GA (2004) Consequences of hypoxia on estuarine ecosystem function: energy diversion from consumers to microbes. Ecol Appl 14:805-822

Banse K, Mosher S (1980) Adult body mass and annual production/biomass relationships of field populations. Ecol Monogr 24:318-324

Benke AC, Hall CAS, Hawkins CS, Lowe-McConnell RH, Stanford JA, Suberkropp K, Ward JV (1988) Bioenergetic considerations in the analysis of stream ecosystems. J N Am Benthol Soc 7:480-502

Blake RE, Duffy JE (2012) Changes in biodiversity and environmental stressors influence community structure of an experimental eelgrass Zostera marina system. Mar Ecol Prog Ser 470:41-54

Blumenshine SC, Kemp WM (2000) Food versus habitat and limitation for benthic macrofauna in mesohaline regions of Chesapeake Bay. In: Kemp WM, Bartleson R, Blumenshine S, Hagy JD, Boynton WR (eds) Ecosystem models of the Chesapeake Bay relating nutrient loadings, environmental conditions, and living resources: final report 1 May 1998 - April 30 1999. University of Maryland Center for Environmental Science Contribution \#3218, p 13-29

Bologna PA, Heck K Jr (2002) Impact of habitat edges on density and secondary production of seagrass-associated fauna. Estuaries 25:1033-1044

Boynton WR, Garber JH, Summers R, Kemp WM (1995) Inputs, transformations, and transport of nitrogen and phosphorus in Chesapeake Bay and selected tributaries. Estuaries 18:285-314

Brafield AE, Newell GE (1961) The behavior of Macoma balthica (L.). J Mar Biol Ass UK 41:81-87

> Brante A, Hughes RN (2001) Effect of hypoxia on the preyhandling behavior of Carcinus maenas feeding on Mytilus edulis. Mar Ecol Prog Ser 209:301-305

Breitburg DL (1990) Near-shore hypoxia in the Chesapeake Bay: patterns and relationships among physical factors. Estuar Coast Shelf Sci 30:593-609

Breitburg DL, Adamack A, Rose KA, Kolesar SE and others (2003) The pattern and influence of low dissolved oxygen in the Patuxent River, a seasonally hypoxic estuary. Estuaries 26:280-297

Brey T (1990) Estimating productivity of macroinvertebrates from biomass and mean individual weight. Meeresforschung 32:329-343

Brey T (2001) Population dynamics in benthic invertebrates: a virtual handbook. Version 01.2. Available at www. thomas-brey.de/science/virtualhandbook

> Brown JH, Gillooly JF, Allen AP, Savage VM, West GB (2004) Toward a metabolic theory of ecology. Ecology 85: 1771-1789

> Burchard H, Schuttelaars HM (2012) Analysis of tidal straining as a driver for estuarine circulation in well-mixed estuaries. J Phys Oceanogr 42:261-271

Burnham KP, Anderson DR (2002) Model selection and multimodel inference: a practical information-theoretic approach. 2nd edn. Springer, New York, NY

Butman CA, Grassle JP, Webb CM (1988) Substrate choices made by marine larvae settling in still water and in a flume flow. Nature 333:771-773

Chia FS, Rice ME (1978) Settlement and metamorphosis of marine invertebrate larvae. Elsevier, New York, NY

Cloern JE (2001) Our evolving conceptual model of the coastal eutrophication problem. Mar Ecol Prog Ser 210: 223-253

Collman JP, Ghosh S, Dey A, Decreau A (2009) Using a functional enzyme model to understand the chemistry behind hydrogen sulfide induced hibernation. Proc Natl Acad Sci USA 106:22090-22095

Cooksey C, Hyland J (2007) Sediment quality of the Lower St. Johns River, Florida: an integrative assessment of benthic fauna, sediment-associated stressors, and general habitat characteristics. Mar Pollut Bull 54:9-21

> Cooper SR (1995) Chesapeake Bay watershed historical land-use impact on water quality and diatom communities. Ecol Appl 5:703-723

Cooper SR, Brush GS (1991) Long-term history of Chesapeake Bay anoxia. Science 254:992-996

Cowles A, Hewitt JE, Taylor RB (2009) Density, biomass and productivity of small mobile invertebrates in a wide range of coastal habitats. Mar Ecol Prog Ser 384:175-185

Cusson M, Bourget E (2005) Global patterns of macroinvertebrate production in marine benthic habitats. Mar Ecol Prog Ser 297:1-14

> Cusson M, Plante JF, Genest C (2006) Effect of different sampling designs and methods on the estimation of secondary production: a simulation. Limnol Oceanogr Methods 4:38-48

> Dauer DM (1985) Functional morphology and feeding behavior of Paraprionospio pinnata (Polychaeta: Spionidae). Mar Biol 85:143-151

> Dauer DM, Llansó RJ (2003) Spatial scales and probability based sampling in determining levels of benthic community degradation in the Chesapeake Bay. Environ Monit Assess 81:175-186

Dauer DM, Maybury CA, Ewing RM (1981) Feeding behavior and general ecology of several spionid polychaetes from the Chesapeake Bay. J Exp Mar Biol Ecol 54:21-38

Dauer DM, Stokes TL, Barker HR, Ewing RM, Sourbeer JW (1984) Macrobenthic communities of the lower Chesapeake Bay. IV Bay-wide transects and the inner continental shelf. Benthic studies of the lower Chesapeake Bay 7. Int Rev ges Hydrobiol 69:1-22

Davies JM, Payne R (1984) Supply of organic matter to the sediment in the northern North Sea during a spring phytoplankton bloom. Mar Biol 78:315-324

> Diaz RJ (2001) Overview of hypoxia around the world. J Environ Qual 30:275-281

Diaz RJ, Rosenberg R (1995) Marine benthic hypoxia: A review of its ecological effects and the behavioral responses of benthic macrofauna. Oceanogr Mar Biol Annu Rev 33:245-303 
Diaz RJ, Schaffner LC (1990) The functional role of estuarine benthos. In: Haire M, Krome EC (eds) Perspectives on the Chesapeake Bay, 1990. Advances in estuarine sciences. Chesapeake Research Consortium, Gloucester Point, VA, p 25-56

Diaz RJ, Rhoad DC, Blake JA, Kropp RK, Keay KE (2008) Long-term trends of benthic habitats related to reduction in wastewater discharge to Boston Harbor. Estuaries Coasts 31:1184-1197

> Dolbeth M, Lillebø AI, Cardoso PG, Ferreira SM, Pardal MA (2005) Annual production of estuarine fauna in different environmental conditions: an evaluation of the estimation methods. J Exp Mar Biol Ecol 326:115-127

> Dolbeth M, Cusson M, Sousa R, Pardal MA (2012) Secondary production as a tool for better understanding of aquatic ecosystems. Can J Fish Aquat Sci 69:1230-1253

> Douglass JG, France KE, Richardson JP, Duffy JE (2010) Seasonal and interannual change in a Chesapeake Bay eelgrass community: insights into biotic and abiotic control of community structure. Limnol Oceanogr 55: 1499-1520

Edgar GJ (1990) The use of the size structure of benthic macrofaunal communities to estimate faunal biomass and secondary production. J Exp Mar Biol Ecol 137: 195-214

Edgar GJ, Barrett NS (2002) Benthic macrofauna in Tasmanian estuaries: scales of distribution and relationships with environmental variables. J Exp Mar Biol Ecol 270:1-24

Edgar GJ, Shaw C, Watson GF, Hammond LS (1994) Comparisons of species richness, size-structure and production of benthos in vegetated and unvegetated habitats in Western Port, Victoria. J Exp Mar Biol Ecol 176:201-226

Eggleston DB, Bell GW, Amavisca AD (2005) Interactive effects of episodic hypoxia and cannibalism on juvenile blue crab mortality. J Exp Mar Biol Ecol 325:18-26

Fauchald K, Jumars PA (1979) The diet of worms. Oceanogr Mar Biol Ann Rev 17:193-284

Folk RL (1973) Carbonate petrography in the post-Sorbian age. In: Ginsburg RN (ed) Evolving concepts in sedimentology. Studies in Geology, Johns Hopkins University 21: 118-158

Forbes TL, Lopez GR (1990) The effect of food concentration, body size, and environmental oxygen tension on the growth of the deposit-feeding polychaete, Capitella species 1. Limnol Oceanogr 35:1535-1544

> Giere O, Preusse JH, Dubilier N (1999) Tubificoides benedii (Tubificidae, Oliochaeta) - a pioneer in hypoxic and sulfidic environments. An overview of adaptive pathways. Hydrobiologia 406:235-241

Gotelli NJ, Ellison AM (2004) A primer of ecological statistics. Sinauer Associates, Sunderland, MA

Hagy JD (2002) Eutrophication, hypoxia, and trophic transfer efficiency in Chesapeake Bay. PhD dissertation, Center for Environmental Science, University of Maryland, $\mathrm{MA}$

> Hagy JD, Boynton WR, Keefe CW, Wood KV (2004) Hypoxia in Chesapeake Bay, 1950-2001: long-term change in relation to nutrient loading and river flow. Estuaries 27: 634-658

> Hagy JD, Boynton WR, Jasinski DA (2005) Modeling phytoplankton deposition to Chesapeake Bay sediments during winter-spring: interannual variability in relation to river flow. Estuar Coast Shelf Sci 62:25-40

> Hines AH, Comtois KL (1985) Vertical distribution of infauna in sediments of a subestuary of central Chesapeake Bay.
Estuaries 9:296-304

Holland AF, Shaughnessy AT, Scott LC, Dickens A, Gerritsen J, Ranasinghe JA (1988) Long-term benthic monitoring for the Maryland portion of Chesapeake Bay. Versar, Columbia, MD

Jackson GA (2008) Effect of mixed layer depth on phytoplankton removal by coagulation and on the critical depth concept. Deep-Sea Res I 55:766-776

$>$ Kemp WM, Boynton WR, Adolf JE, Boesch DF and others (2005) Eutrophication of Chesapeake Bay: historical trends and ecological interactions. Mar Ecol Prog Ser 303:1-29

Kempf SC, Hadfield MG (1985) Planktotrophy by the lecithotrophic larvae of a nudibranch, Phestilla sibogae (Gastropoda). Biol Bull 169:119-129

Kodama K, Aoki I, Shimizu M, Taniuchi T (2002) Long-term changes in the assemblage of demersal fishes and invertebrates in relation to environmental variation in Tokyo Bay, Japan. Fish Manag Ecol 9:303-313

> Koehl MAR, Hadfield MG (2010) Hydrodynamics of larval settlement from a larva's point of view. Integr Comp Biol 50:539-551

Kravitz MJ (1983) Niche relations among polychaetes of a meso-polyhaline assemblage of the York River, Virginia. Masters thesis, Virginia Institute of Marine Science, The College of William \& Mary, Gloucester Point, VA

$>$ Kuo AY, Neilson BJ (1987) Hypoxia and salinity in Virginia estuaries. Estuaries 10:277-283

Kuo AY, Park K, Moustafa MZ (1991) Spatial and temporal variabilities of hypoxia in the Rappahannock River, Virginia. Estuaries 14:113-121

Lamont PA, Gage JD (2000) Morphological responses of macrobenthic polychaetes to low oxygen on the Oman continental slope, NW Arabian Sea. Deep-Sea Res II 47: 9-24

Levin LA (2003) Oxygen minimum zone benthos: adaptation and community response to hypoxia. Oceanogr Mar Biol Annu Rev 41:1-45

Levin LA (2006) Recent progress in understanding larval dispersal: new directions and digressions. Integr Comp Biol 46:282-297

Levin LA, Huggett DV (1990) Implication of alternative reproductive modes for seasonality and demography in an estuarine polychaete. Ecology 71:2191-2208

> Levin LA, Caswell H, DePatra KD, Creed EL (1987) Demographic consequences of larval development mode: planktotrophy vs. lecithotrophy in Streblospio benedicti. Ecology 68:1877-1886

Levin LA, Ekau W, Gooday AJ, Jorissen F and others (2009) Effects of natural and human-induced hypoxia on coastal benthos. Biogeosciences 6:2063-2098

Lindeman RL (1942) The trophic-dynamic aspect of ecology. Ecology 23:399-418

Llansó RJ (1990) Effects of low dissolved oxygen on the macrobenthos of the lower Rappahannock River, Chesapeake Bay. PhD dissertation. Virginia Institute of Marine Science, College of William and Mary, Gloucester Point, VA

Llansó RJ (1991) Tolerance of low dissolved oxygen and hydrogen sulfide by the polychaete Steblospio benedicti (Webster). J Exp Mar Biol Ecol 153:165-178

Llansó RJ (1992) Effects of hypoxia on estuarine benthos: the lower Rappahannock River (Chesapeake Bay), a case study. Estuar Coast Shelf Sci 35:491-515

Lohrer AM, Thrush SF, Gibbs MM (2004) Bioturbators 
enhance ecosystem function through complex biogeochemical interactions. Nature 431:1092-1095

Long WC, Seitz RD (2008) Trophic interactions under stress: hypoxia enhances foraging in an estuarine food web. Mar Ecol Prog Ser 362:59-68

Long WC, Brylawski BJ, Seitz RD (2008) Behavioral effects of low dissolved oxygen on the bivalve Macoma balthica. J Exp Mar Biol Ecol 359:34-39

Lu L, Wu RSS (1998) Recolonization and succession of marine macrobenthos in organic-enriched sediment deposited from fish farms. Environ Pollut 101:241-251

Ludsin SA, Zhang X, Brandt SB, Roman MR and others (2009) Hypoxia-avoidance by planktivorous fish in Chesapeake Bay: implications for food web interaction and fish recruitment. J Exp Mar Biol Ecol (Suppl) 381: S121-S131

Magnien R, Boward D, Bieber S (1995) The state of the Chesapeake 1995. US Environmental Protection Agency, Annapolis, MD

Mee LD (2005) Assessment and monitoring requirements for the adaptive management of Europe's regional seas. In: Vermaat J, Bouwer L, Turner K, Salomons W (eds) Managing European coasts. Springer-Verlag, Berlin, p 227-237

Meysman FJR, Middelburg JJ, Heip CHR (2006) Bioturbation: a fresh look at Darwin's last idea. Trends Ecol Evol 21:688-695

> Morin A, Bourassa N (1992) Modeles empiriques de la production annuelle et $\mathrm{du}$ rapport $\mathrm{P} / \mathrm{B}$ d'invertebres benthiques d'eau courantes. Can J Fish Aquat Sci 49: 532-539

Murphy RR, Kemp WM, Ball WP (2011) Long-term trends in Chesapeake Bay seasonal hypoxia, stratification, and nutrient loading. Estuaries Coasts 34:1293-1309

Nestlerode JA, Diaz RJ (1998) Effects of periodic environmental hypoxia on predation of a tethered polychaete, Glycera americana: implication for trophic dynamics. Mar Ecol Prog Ser 172:185-195

> Newcombe CL, Horne WA, Shepherd BB (1939) Studies on the physics and chemistry of estuarine waters in Chesapeake Bay. J Mar Res 2:87-116

Nichols FH (1977) Dynamics and production of Pectinaria koreni (Malmgren) in Kiel Bay, West Germany. In: Keegan BF, Ceidigh PO, Boaden PJS (eds) Biology of benthic organisms. Pergamon Press, Oxford, p 453-463

Nilsen M, Pedersen T, Nilssen EM (2006) Macrobenthic biomass, productivity $(\mathrm{P} / \mathrm{B})$ and production in a high-latitude ecosystem, North Norway. Mar Ecol Prog Ser 321: $67-77$

Officer CB, Biggs RB, Taft JL, Cronin LE, Tyler MA, Boynton WR (1984) Chesapeake Bay anoxia: origin, development, and significance. Science 223:22-27

Park K, Kuo AY, Neilson J (1996) A numerical model study of hypoxia in the tidal Rappahannock River of Chesapeake Bay. Estuar Coast Shelf Sci 42:563-581

Pearson TH, Rosenberg R (1978) Macrobenthic succession in relation to organic enrichment and pollution of the marine environment. Oceanogr Mar Biol Annu Rev 16: 229-311

Perkins EJ (1974) The biology of estuaries and coastal waters. Academic Press, London

> Pihl L, Baden SP, Diaz RJ, Schaffner LC (1992) Hypoxiainduced structural changes in the diet of bottom feeding fish and crustacea. Mar Biol 112:349-361

Plante C, Downing JA (1989) Production of freshwater invertebrate populations in lakes. Can J Fish Aquat Sci
46:1489-1498

Powers SP, Harper DE Jr, Rabalais NN (2001) The effect of large scale hypoxia/anoxia on the supply and settlement of benthic invertebrate larvae. In: Rabalais NN, Turner RE (eds) Coastal hypoxia: consequences for living resources. Coastal and Estuarine Studies 58. American Geophysical Union, Washington, DC, p 165-184

> Powers SP, Peterson CH, Christian RR, Sullivan E, Powers MJ, Bishop MJ, Buzzelli CP (2005) Effects of eutrophication on bottom habitat and prey resources of demersal fishes. Mar Ecol Prog Ser 302:233-243

> Rabalais NN, Turner RE, Wiseman WJ Jr (2001) Hypoxia in the Gulf of Mexico. J Environ Qual 30:320-329

Rainer SF (1982) Trophic structure and production in the macrobenthos of a temperate Australian estuary. Estuar Coast Shelf Sci 15:423-441

Rakocinski CF (2012) Evaluating macrobenthic process indicators in relation to organic enrichment and hypoxia. Ecol Indic 13:1-12

Rakocinski CF, Zapfe GA (2005) Macrobenthic process indicators of estuarine conditions. In: Bortone SA (ed) Estuarine indicators. CRC Press, Boca Raton, FL, p 315-331

$>$ Reed DC, Raimondi PT, Carr MH, Goldwasser L (2000) The role of dispersal and disturbance in determining spatial heterogeneity in sedentary organisms. Ecology 81: 2011-2026

> Revsbech NP, Sorensen J, Blackburn TH (1980) Distribution of oxygen in marine sediments measured with microelectrodes. Limnol Oceanogr 25:403-411

> Riedel B, Zuschin M, Haselmair A, Stachowitsch M (2008) Oxygen depletion under glass: behavioural responses of benthic macrofauna to induced anoxia in the Northern Adriatic. J Exp Mar Biol Ecol 367:17-27

Robertson AI (1979) The relationship between annual production: biomass ratios and lifespans for marine macrobenthos. Oecologia 38:193-202

> Rosenberg R (1972) Benthic faunal recover in a Swedish fjord following the closure of a sulphite pulp mill. Oikos 23:92-108

> Rosenberg R, Agrenius S, Hellman B, Nilsson HC, Norling K (2002) Recovery of marine benthic habitats and fauna in a Swedish fjord following improved oxygen conditions. Mar Ecol Prog Ser 234:43-53

Sagasti A, Schaffner LC, Duffy JE (2001) Effects of periodic hypoxia on mortality, feeding and predation in an estuarine epifaunal community. J Exp Mar Biol Ecol 258: 257-283

Sale JW, Skinner WW (1917) The vertical distribution of dissolved oxygen and the precipitation of salt water in certain tidal areas. J Franklin Inst 184:837-848

Sandifer PA (1972) Morphology and ecology of Chesapeake Bay decapod crustacean larvae. PhD dissertation, University of Virginia, VA

Schaffner LC (1987) Ecology of the benthso of the lower Chesapeake Bay. PhD Dissertation, Virginia Institute of Marine Science, College of William \& Mary, Gloucester Point, VA

> Schwinghamer P, Hargrave B, Peer D, Hawkins CM (1986) Partitioning of production and respiration among size groups of organisms in an intertidal benthic community. Mar Ecol Prog Ser 31:131-142

Seitz RD, Marshall LS Jr, Hines AH, Clark KL (2003) Effects of hypoxia on predator-prey dynamics of the blue crab Callinectes sapidus and the Baltic clam Macoma balthica in Chesapeake Bay. Mar Ecol Prog Ser 257:179-188 
Seitz RD, Dauer DM, Llansó RM, Long WC (2009) Broadscale effects of hypoxia on benthic community structure in Chesapeake Bay, USA. J Exp Mar Biol Ecol (Suppl) 381:S4-S12

Shumway SE, Scott TM, Shick TM (1993) The effects of anoxia and hydrogen sulfide on survival, activity and metabolic rate in the root clam, Mulinia lateralis (Say). J Exp Mar Biol Ecol 71:135-146

Simon JL (1967) Reproduction and larval development of Spio setosa (Spionidae; Polychaeta). Bull Mar Sci 17: 398-431

Solan M, Kennedy R (2002) Observation and quantification of in situ animal-sediment relations using time-lapse sediment profile imagery (t-SPI). Mar Ecol Prog Ser 228: 179-191

Sprung M (1993) Estimating secondary production from body weight and mass: a field test in a non-boreal intertidal habitat. Mar Ecol Prog Ser 100:103-109

Stow CA, Scavia D (2009) Modeling hypoxia in the Chesapeake Bay: ensemble estimation using a Bayesian hierarchical model. J Mar Syst 76:244-250

Sturdivant SK (2011) The effects of hypoxia on macrobenthic production and function in the lower Rappahannock river, Chesapeake Bay, USA. PhD dissertation, Virginia Institute of Marine Science, College of William \& Mary, Gloucester Point, VA

Sturdivant SK, Diaz RJ, Cutter GR (2012) Bioturbation in a declining oxygen environment, in situ observations from Wormcam. PLoS ONE 7:e34539

Taft JL, Taylor WR, Hartwig ED, Loftus ED (1980) Seasonal oxygen depletion in Chesapeake Bay. Estuaries 3: 242-247

Telesh IV, Khlebovich VV (2010) Principal processes within estuarine salinity gradient: a review. Mar Pollut Bull 61: 149-155

Tevesz MJS, Soster FM, McCall PL (1980) The effects of sizeselective feedign by oligochaetes on the phyical properties of river sediments. J Sediment Petrol 50:561-568

Thorson G (1950) Reproduction and larval ecology of marine bottom invertebrates. Biol Rev Camb Philos Soc 25:1-45

Torrans EL, Clemens HP (1982) Physiological and biochem-

Editorial responsibility: William Kemp,

Cambridge, Maryland, USA ical effects of acute exposure of fish to hydrogen sulfide. Comp Biochem Physiol C 71:183-190

Tumbiolo ML, Downing JA (1994) An empirical model for the prediction of secondary production in marine benthic invertebrate populations. Mar Ecol Prog Ser 114:165-174

Tyson RV, Pearson TH (1991) Modern and ancient continental shelf anoxia: an overview. Geol Soc Lond Spec Pub $58: 1-24$

Van Colen C, Montserrat F, Vincx M, Herman PMJ, Ysebaert T, Degraer S (2010) Long-term divergent tidal flat benthic community recovery following hypoxia-induced mortality. Mar Pollut Bull 60:178-186

Vaquer-Sunyer R, Duarte CM (2008) Thresholds of hypoxia for marine biodiversity. Proc Natl Acad Sci USA 105: 15452-15457

Vaquer-Sunyer R, Duarte CM (2010) Sulfide exposure accelerates hypoxia-driven mortality. Limnol Oceanogr 55: 1075-1082

Wannamaker CM, Rice JA (2000) Effects of hypoxia on movements and behavior of selected estuarine organisms from the southeastern United States. J Exp Mar Biol Ecol 249:145-163

- Warren LM (1976). A population study of the polychaete Capitella capitata at Plymouth. Mar Biol 38:209-216

> Watzin MC (1986) Larval settlement into marine softsediment systems: interactions with the meiofauna. J Exp Mar Biol Ecol 98:65-113

Wiegert RG (1988) The past, present, and future of ecological energetic. In: Pomeroy LR, Alberts JJ (eds) Concepts of ecosystem ecology. Springer-Verlag, New York, NY, p 29-55

> Wilber DH, Clarke DG (1998) Estimating secondary production and benthic consumption in monitoring studies: a case study of the impacts of dredged material disposal in Galveston Bay, Texas. Estuaries 21:230-245

Zar JH (1999) Biostatistical analysis, 4th edn. Prentice Hall, Upper Saddle River, NJ

> Zimmerman AR, Canuel EA (2000) A geochemical record of eutrophication and anoxia in Chesapeake Bay sediments: anthropogenic influence on organic matter composition. Mar Chem 69:117-137

Submitted: December 20, 2012; Accepted: July 2, 2013

Proofs received from author(s): September 2, 2013 